\title{
HIV Education and Welfare Services in Primary Care: An Empirical Model of Integration in Brazil's Unified Health System
}

\author{
Rahbel Rahman ${ }^{1, *}$, Rogério M. Pinto ${ }^{2}$ and Melanie M. Wall ${ }^{3}$ \\ 1 Department of Social Work, Community of College and Public Affairs, Binghamton University, \\ 67 Washington St, Binghamton, NY 13902, USA \\ 2 School of Social Work, University of Michigan, 1080 S University Ave, Ann Arbor, MI 48109, USA; \\ ropinto@umich.edu \\ 3 Department of Biostatistics, Columbia University, 722 West 168th St. New York, NY 10032, USA; \\ mmw2177@cumc.columbia.edu \\ * Correspondence: rrahman@binghamton.edu; Tel.: +1-607-777-9188 \\ Academic Editor: Peng Bi \\ Received: 19 January 2017; Accepted: 8 March 2017; Published: 14 March 2017
}

\begin{abstract}
Integration of health education and welfare services in primary care systems is a key strategy to solve the multiple determinants of chronic diseases, such as Human Immunodeficiency Virus Infection and Acquired Immune Deficiency Syndrome (HIV / AIDS). However, there is a scarcity of conceptual models from which to build integration strategies. We provide a model based on cross-sectional data from 168 Community Health Agents, 62 nurses, and 32 physicians in two municipalities in Brazil's Unified Health System (UHS). The outcome, service integration, comprised HIV education, community activities (e.g., health walks and workshops), and documentation services (e.g., obtainment of working papers and birth certificates). Predictors included individual factors (provider confidence, knowledge/skills, perseverance, efficacy); job characteristics (interprofessional collaboration, work-autonomy, decision-making autonomy, skill variety); and organizational factors (work conditions and work resources). Structural equation modeling was used to identify factors associated with service integration. Knowledge and skills, skill variety, confidence, and perseverance predicted greater integration of HIV education alongside community activities and documentation services. Job characteristics and organizational factors did not predict integration. Our study offers an explanatory model that can be adapted to examine other variables that may influence integration of different services in global primary healthcare systems. Findings suggest that practitioner trainings to improve integration should focus on cognitive constructs-confidence, perseverance, knowledge, and skills.
\end{abstract}

Keywords: HIV/AIDS; social services; service integration; interprofessional collaboration

\section{Introduction}

Across the globe, Human Immunodeficiency Virus Infection and Acquired Immune Deficiency Syndrome (HIV/AIDS) continues to disproportionately burden low-income ethnic/racial groups and sexual minorities who face myriad other chronic diseases [1-3]. In 2015, 830,000 people were living with HIV in Brazil, the prevalence for adults aged 15 to 49 was $0.6 \%$, with the highest rates in populations facing low educational attainment and economic inequality [4]. HIV risk behaviors arise within the context of socioeconomic determinants of health, such as the physical, familial, cultural, organizational, economic, policy/legal, and social environments in which those affected live $[5,6]$. Given the scope of these determinants of health, governments worldwide, including Brazil, have 
developed workforces to provide HIV / AIDS prevention education while also assisting low-income individuals to obtain documentation (e.g., birth certificates, working papers, identity cards, etc.) for receiving primary care and welfare services (e.g., provision of nutritious food, etc.) $[7,8]$.

Lack of consensus on a definition for service integration (e.g., in this case, the integration of HIV education with community activities and documentation services) has delayed research on the inclusion of different services into primary care $[9,10]$. "Service integration" by various authors has been used to refer to integrated care, continuity of care, coordinated care, managed care, comprehensive care, and patient-centered care [11]. There have been a number of studies that have confirmed the feasibility of integrating different services with primary care, such as mental health and drug treatment [12,13]. Integration has been shown to be a cost-effective tool [14] with the potential to improve disease treatment response, increase the likelihood of remission $[15,16]$ and access to services [17], and improve patient well-being [17]. What remains unknown is how best to integrate HIV education with welfare-related services within primary care systems [10].

This paper advances the literature by providing an explanatory framework within which to build further research on service integration. We define "service integration" as the coordinated behaviors of practitioners in the Estratégia Saúde da Família (FHS; Family Health Strategy), the primary care program of Brazil's Sistema Único de Saúde (UHS; Unified Health System), which offers multiple services to individuals at risk for multiple disorders and diseases. The UHS employs physicians, nurses, and Agentes Comunitários da Saúde in Portuguese or in English as community health agents (CHAs), all charged with the integration of welfare and public health services within primary-care units across the country [18]. The purpose of our study was to identify significant predictors of service integration at the practitioner and organizational levels along with practitioners' job characteristics. The authors believe that the framework can be adopted by other researchers to study the integration of welfare services with other chronic diseases, such as tuberculosis (TB), cancer, etc.

\subsection{Service Integration in Brazil's Family Health Strategy}

The FHS has institutionalized the provision of health and welfare services to comply with Brazil's 1988 federal constitution and the 1990 Lei Orgânica da Saúde (Organic Health Law) [19]. The FHS offers free primary health care through a decentralized system, deploying interprofessional teams, each comprised of one physician, a nurse, two or three nurse assistants, and four to six CHAs. Each team provides care to between 800 and 1000 families, representing some 4000 individuals [20]. Collectively, the FHS teams provide primary care to more than 60 million Brazilian citizens [19]. According to Brazil's National Standards, physicians, nurses, and CHAs, are involved in the provision of services in three key domains, as follows. HIV education comprises teaching community residents about how to access HIV testing and free condoms, how to use condoms, and how to practice safe needle exchange [21]. The FHS is involved in helping patients obtain documentation, such as birth certificates, working papers, identity cards, etc., needed for receiving primary care and welfare services. One must be a Brazilian citizen to qualify for services, for example, the cesta básica (food basket), a program that offers nutritious food for families living below the poverty line. Documentation is a crucial issue in a universal healthcare system to track Brazil's most prevalent health problems and prioritize interventions to address them [20,22]. FHS teams also involve residents in sociocultural activities, including education campaigns to improve HIV knowledge, address stigma, and debunk HIV myths [23].

\subsection{Factors That Influence Integration}

Knowledge base, skills, perseverance, confidence, perception of team efficacy, and familiarity with the communities all influence how practitioners integrate different services. Whereas nurses and physicians possess biomedical knowledge (i.e., etiology and epidemiology of diseases) [24], CHAs (or Community Health Workers (CHWs), as known globally) are trained in basic medical practices and are specifically hired to use their lived experiential knowledge to impart health-promoting behaviors [25]. 
CHAs may acquire their lived experiential knowledge through having greater familiarity with communities' lifestyles, traditions, and habits than physicians and nurses are intended to have [26]. Physicians and nurses often lack training in building partnerships with consumers to stimulate change within local communities [22,27]. Nonetheless, CHAs may assist medical practitioners with socio-emotional counseling skills [25]. The process of sharing their skills and knowledge can enhance practitioners' confidence to provide both social and medical services [28].

Work conditions and available resources, such as office space, medical supplies, and data management systems, all comprise organizational factors that influence how different practitioners in a health team contribute to integrating services $[29,30]$. FHS uses discrete, formalized assignments for staff, while encouraging all practitioners to work together to combine different services. Though the roles and responsibilities of each FHS practitioner might be specific, FHS practitioners are not precluded from providing those services. While physicians are charged with developing care plans, nurses perform nursing care, request laboratory tests, dispense medications, supervise CHAs, and engage in health promotion activities [31]. CHAs collect and manage household data on births, deaths, disease incidence, and immunization status of children -in addition to offering health promotion activities $[32,33]$. Therefore, FHS practitioners integrate services by pooling their knowledge, skills, and cognitive competencies discussed above [34].

Several job-related variables, practitioners' assignments and their discretion to perform such assignments, may influence their decisions concerning when and how to integrate different services $[35,36]$. For example, federal guidelines encourage FHS practitioners to account for the input of consumers as co-creators in their own health care $[37,38]$. Interprofessional collaboration, another important influence in integration, is characterized by practitioners working side by side, applying diverse knowledge/solutions to health issues. Other job-related factors include "practitioner autonomy" and "skill variety" [35]. Autonomy gives practitioners confidence that they are able to deal immediately with a consumer's health issues [39]. Skill variety is a concept that arises from practitioner autonomy; in order for practitioners to offer consumers a wider range of services, they must possess diverse skill sets, such as the ability to integrate health and welfare services into their practices [40].

CHAs are hired from the communities in which they live, but most nurses and physicians reside outside the poor communities that they serve [20]. Yet the practitioners' socio-geographic relationships to the communities they serve has received little attention in the literature. In this study, we examined whether or not practitioners living closer to the communities they served were better able to tailor prevention services to the needs of those communities.

\subsection{Theoretical Framework}

Our theoretical framework (Figure 1) reflects concepts of Cognitive-Behavioral Theory, Job Characteristics Theory [41], Modern Organizational Development Theory [42], and Structural Contingency Theory $[43,44]$. Cognitive Behavioral Theory reflects intrapersonal factors that influence practitioners' service integration. Job Characteristics Theory suggests that practitioners' integration of services can be influenced by their prescribed roles, by expected organizational norms, and by the presence or absence of organizational structure and of human and material resources. Practitioners are also influenced by their organization's size/capacities, climate, and culture. Organizational theories, such as modern organizational developmental theory and structural contingency theory, explain how practitioners behave within community-based organizations, such as the FHS, that are systematized around provision of medical services. 


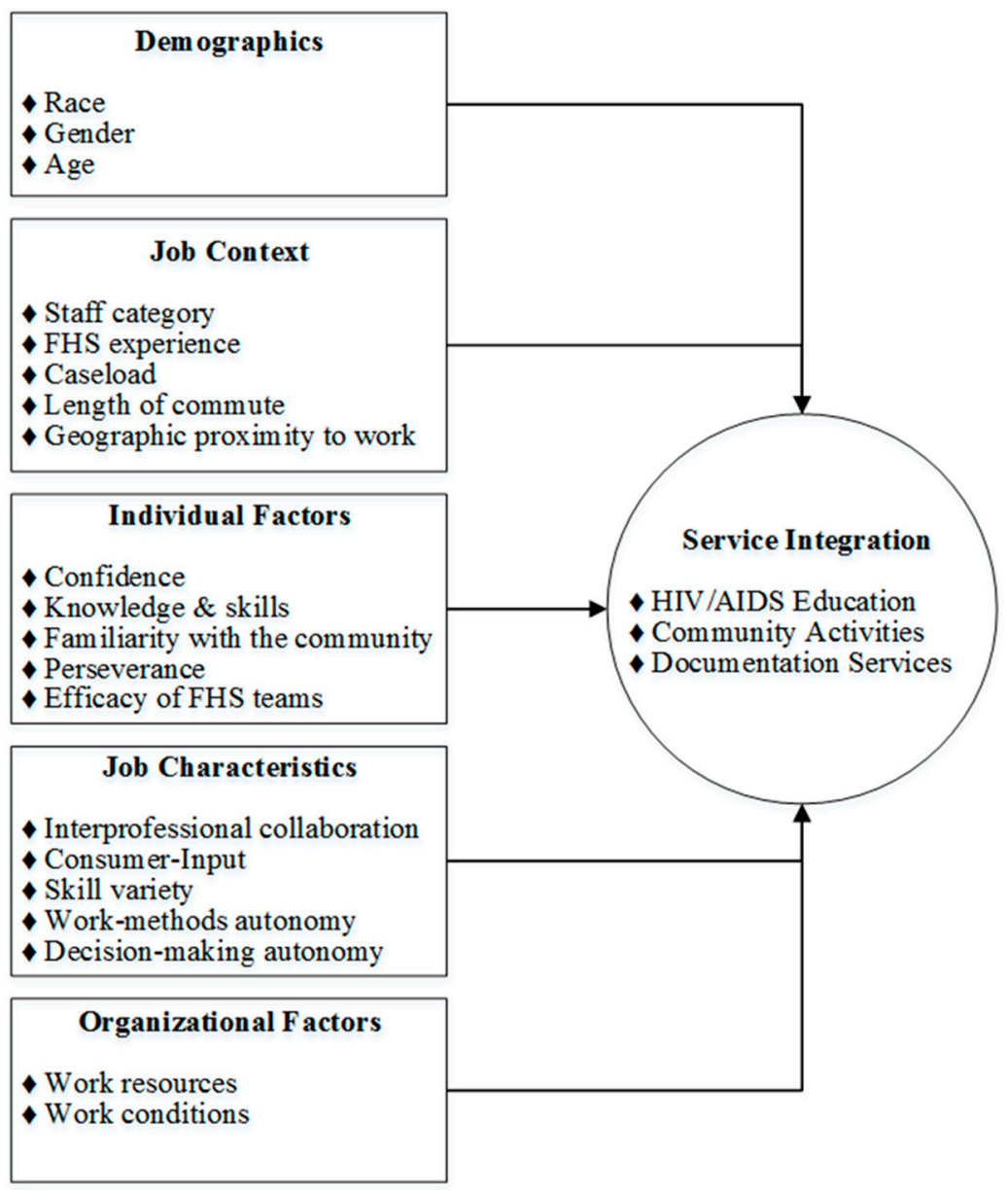

Figure 1. Service Integration Framework. FHS: Estratégia Saúde da Família (Family Health Strategy); Human Immunodeficiency Virus Infection and Acquired Immune Deficiency Syndrome (HIV/AIDS).

\section{Materials and Methods}

This study was approved by the Institutional Review Boards of Columbia University, New York, NY, USA, (IRB-AAAC4674 (Y2M01)) and Universidade Católica, Rio de Janeiro, RJ, Brazil. This study followed a community-engaged strategy that included university partners, health care administrators, and CHAs who developed the study's aims and methods and plans for disseminating findings [45]. Written consent was sought from all study participants. Collaborating with FHS administrators helped us to establish study aims that would produce results that would be beneficial to the communities in which the study would take place [46].

\subsection{Sampling and Recruitment}

We enrolled 168 CHAs, 62 nurses, and 32 physicians from 30 Unidades Básicas de Saúde (UBS), also known as community-based primary health care clinics, in two Brazilian municipalities. Through the UBS, FHS teams provide primary health care services. Each UBS had at least one physician (range $=1-2$ ), one nurse (range $=1-5$ ), and one CHA (range $=1-23$ ). The average length of employment was 40 months $(\mathrm{SD}=31$; range $=4-156)$. Participation was voluntary. Brazil's policy on research does not permit financial incentives; however, refreshments were provided during data collection. 


\subsection{Data Collection}

Eight master's level Brazilian interviewers were trained in research methods and procedures, and administered the survey using password-protected mobile computers. Data were downloaded into a password-protected database, DatStat Illume 4.6 (DatStat, Seattle, WA, USA) [47]. All data were kept in password-secured computer files, to which only relevant research personnel had access. There was no documentation linking respondents assigned ID numbers to the UBS for which they worked. The survey was administered verbally and lasted from 45 to $75 \mathrm{~min}$. Approximately $85 \%$ of staff from all clinics participated.

\subsection{Multidimensional Survey}

Survey questions addressed participants' perceptions of and attitudes toward their knowledge, skills and confidence, and job characteristics. We piloted the survey with 42 practitioners. CHAs showed difficulty understanding questions that tapped opinions and attitudes toward scientific research, and physicians found the survey too long. We used this input to modify the survey. Survey questions were then translated from Portuguese to English and iteratively back-translated into Portuguese [48] for accuracy.

\subsection{Measures}

All predictor variables appear in Table 1. The outcome, service integration, was measured by combining three dichotomous (yes/no) variables: (1) "I teach consumers how to prevent HIV and AIDS"; (2) "I help my consumers obtain documents, such as voter registration, working papers, and birth certificates"; and (3) "I help my consumers get involved in community activities, such as health walks and workshops." Though each of the three integration variables may align more closely with the roles and job descriptions of one or another FHS provider, these services can be provided by all providers. Moreover, our measure of "integration" follows our conceptual framework in that integration is conceptualized as the combination of different services performed by different providers.

Demographics included "age" measured as a continuous variable; "gender" included male or female; "race" included Black, White, and Pardo (Pardo refers to mixed races, such as mulattos [49]).

\subsection{Data Analysis}

We summarized descriptive frequencies of demographics and job context variables. We investigated influences on FHS teams' provision of HIV/AIDS education along with their involvement of consumers in community-level activities and helping them to obtain documentation/registration, "service integration," as a latent variable underlying three measures: HIV / AIDS education; community activities; and documentation services (Figure 1). We used MPlus 7.1 software (Muthén \& Muthén, Los Angeles, CA, USA) to fit the structural equation model following the form on Figure 1 using the weighted least squares estimation appropriate for categorical outcomes. The $\chi^{2}$ goodness of fit test, the ratio of the $\chi^{2}$ to the degrees of freedom, and the root mean square error of approximation (RMSEA) were used to assess fit. An RMSEA value of $\leq 0.05$ signifies a good fit [51], and as the $\chi^{2}$ statistic tends to be over-sensitive to minor misfit, the ratio of the $\chi^{2}$ to the d.f (degrees of freedom) $<2$ is often considered good fit [52]. The percent of variability in the latent service integration variable explained by all the predictors in the model was used to quantify explanatory power of the model. Modification indices (MIs) were tested to examine any possible direct effects between the predictors and the three observed measures of service integration (above and beyond the effects through the latent service integration variable). 
Table 1. Predictors of Service Integration.

\begin{tabular}{|c|c|c|}
\hline Predictors & Definition & Item(s) and Scale \\
\hline \multicolumn{3}{|c|}{ Individual Factors } \\
\hline \multirow[b]{2}{*}{ Knowledge and skills } & & $\begin{array}{l}5 \text {-point Likert scale } \\
(1=\text { strongly disagree to } 5=\text { strongly agree })\end{array}$ \\
\hline & $\begin{array}{l}\text { 10-item composite: abilities to ask client/patients } \\
\text { questions to provoke discussions about health, disease } \\
\text { prevention, side effects of medications, and available } \\
\text { resources (Cronbach } \alpha=0.757 \text { ) }\end{array}$ & $\begin{array}{l}\text { - I know how to ask questions to help client/patients discuss } \\
\text { their health } \\
\text { - I know how to ask questions about health risks } \\
\text { - I know how to ask questions about medication side effects }\end{array}$ \\
\hline \multirow[b]{2}{*}{ Confidence } & & $\begin{array}{l}5 \text {-point Likert scale } \\
(1=\text { strongly disagree to } 5=\text { strongly agree })\end{array}$ \\
\hline & $\begin{array}{l}\text { 3-item composite: appraisals of ability to provide } \\
\text { client/patients with adequate services } \\
\text { (Cronbach } \alpha=0.521 \text { ) }\end{array}$ & $\begin{array}{l}\text { - I know exactly what my client/patient needs are } \\
\text { - I am able to make treatment plans which fit the needs and abilities of } \\
\text { my patient } \\
\text { - I am able to address client/patient needs }\end{array}$ \\
\hline \multirow[b]{2}{*}{ Perseverance } & & $\begin{array}{l}\text { 5-point Likert scale } \\
(1=\text { strongly disagree to } 5=\text { strongly agree })\end{array}$ \\
\hline & $\begin{array}{l}\text { Single item: extent of practitioner commitment to } \\
\text { providing the best services }\end{array}$ & $\begin{array}{l}\text { - I am committed to delivering the best services possible to the } \\
\text { families in my catchment area, even when they are difficult }\end{array}$ \\
\hline \multirow[b]{2}{*}{ Efficacy of FHS teams } & & $\begin{array}{l}5 \text {-point Likert scale } \\
(1=\text { strongly disagree to } 5=\text { strongly agree })\end{array}$ \\
\hline & Single item: practitioner perception of team efficacy & $\begin{array}{l}\text { - The existence of FHS teams has improved the quality of health in my } \\
\text { catchment area }\end{array}$ \\
\hline \multirow[b]{2}{*}{ Familiarity with the community } & & Dichotomous (yes or no) \\
\hline & $\begin{array}{l}\text { Single item: extent to which practitioner knew } \\
\text { the community }\end{array}$ & - I know the latest news in my catchment area affecting client/patients \\
\hline
\end{tabular}


Table 1. Cont

\begin{tabular}{|c|c|c|}
\hline Predictors & Definition & Item(s) and Scale \\
\hline \multicolumn{3}{|c|}{ Job Characteristics } \\
\hline \multirow[b]{2}{*}{ Inter-professional collaboration } & & $\begin{array}{l}\text { 5-point Likert scale } \\
(1=\text { strongly disagree to } 5=\text { strongly agree })\end{array}$ \\
\hline & $\begin{array}{l}\text { 5-item composite: extent to collaboration between } \\
\text { different professions } \\
\text { (Cronbach } \alpha=0.640 \text { ) }\end{array}$ & $\begin{array}{l}\text { - I utilize other colleagues in deciding interventions } \\
\text { - } \quad \text { I have access to colleagues when I need help } \\
\text { - Team meetings are important }\end{array}$ \\
\hline \multirow[b]{2}{*}{ Consumer-Input } & & $\begin{array}{l}5 \text {-point Likert scale } \\
(1=\text { strongly disagree to } 5=\text { strongly agree })\end{array}$ \\
\hline & $\begin{array}{l}\text { 4-item composite: extent practitioner value/use } \\
\text { client/patient input } \\
\text { (Cronbach } \alpha=0.627 \text { ) }\end{array}$ & $\begin{array}{l}\text { - My client/patient values and preferences are very important } \\
\text { - My client/patient goals are very important } \\
\text { - My client/patient and I work together to address needs } \\
\text { - With client/patients' help, I monitor client/patient outcomes }\end{array}$ \\
\hline \multirow{3}{*}{ Skill variety } & & $\begin{array}{l}5 \text {-point Likert scale } \\
(1=\text { strongly disagree to } 5=\text { strongly agree })\end{array}$ \\
\hline & $\begin{array}{l}\text { 3-item composite: extent of variety in skill sets } \\
\text { (Cronbach } \alpha=0.620)\end{array}$ & $\begin{array}{l}\text { - I am able to understand and use protocols } \\
\text { - I have the knowledge/skills to bring together information from } \\
\text { different sources to address my client/patient's needs } \\
\text { - I know how to use new information to treat my client/patient }\end{array}$ \\
\hline & & Dichotomous: $(0=$ Disagree; $1=$ Agree $)$ \\
\hline \multirow[t]{2}{*}{ Work autonomy } & Single item: perception of work-related autonomy & $\begin{array}{l}\text { - I can tailor my work based on the information I gathered from my } \\
\text { client/patient and from research }\end{array}$ \\
\hline & & Dichotomous: $(0=$ Disagree; 1 = Agree $)$ \\
\hline Decision-making autonomy & Single item: perception of work-decision-making & $\begin{array}{l}\text { - I am able to change or alter treatment based on changes in the needs } \\
\text { of the client/patient }\end{array}$ \\
\hline
\end{tabular}


Table 1. Cont.

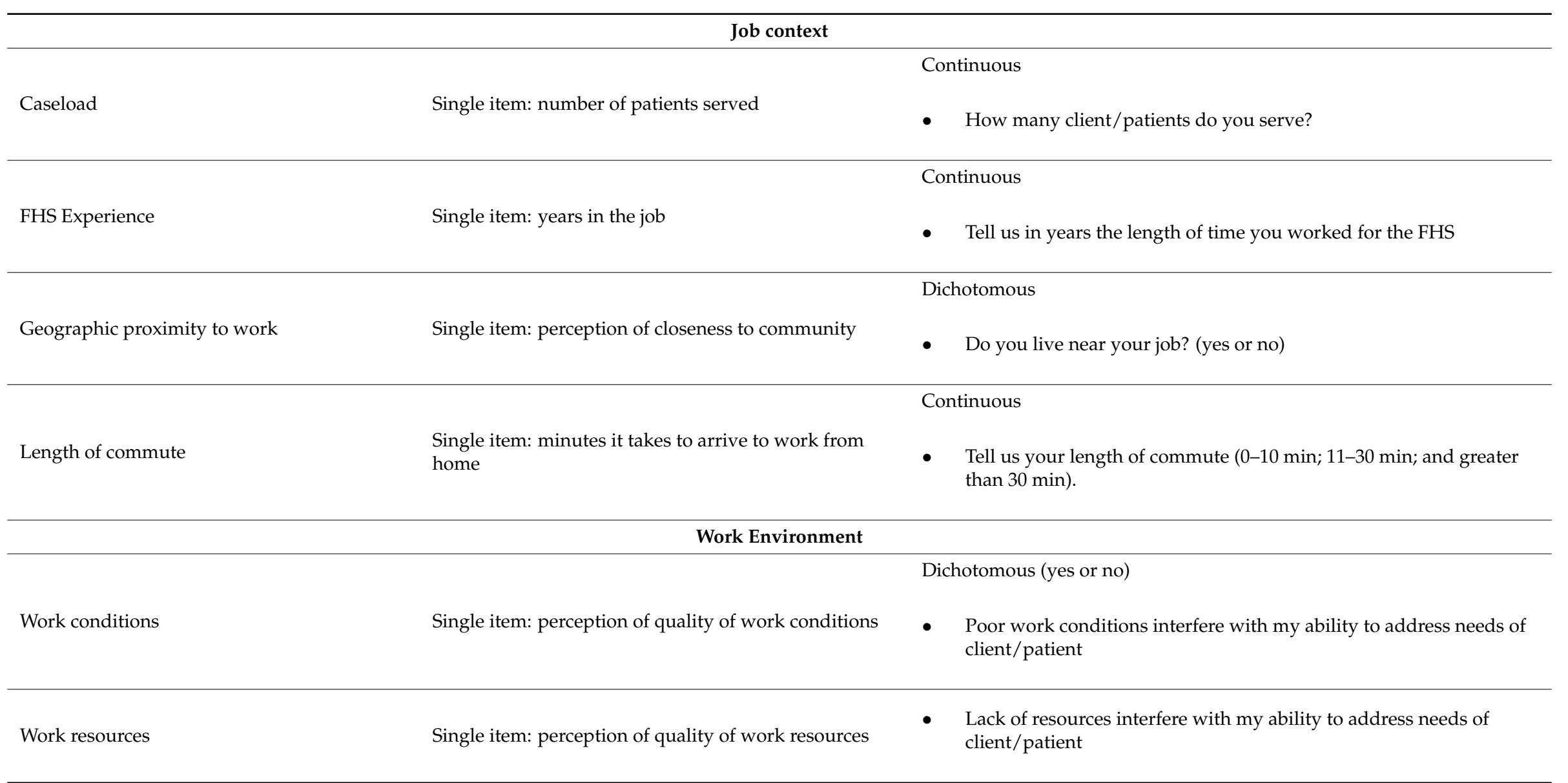

All Cronbach alphas greater than 0.5, considered "reasonably good" when the subject matter under examination is novel (newly developed measures used in the analysis) ([50], p. 70);

FHS: Family Health Strategy. 


\section{Results}

\subsection{Sample Characteristics}

Table 2 shows that most respondents were CHAs $(n=169 ; 64 \%)$; 62 were nurses (24\%); and 31 were physicians (12\%). The highest proportion of respondents identified as Pardo $(n=123 ; 47 \%) ; 82$ were White $(32 \%)$; and $54(21 \%)$ were Black. The majority were female $(n=214 ; 82 \%)$. Average age was 33.60 $(\mathrm{SD}=9.99$, range $=20-70)$. The majority of practitioners $(n=175 ; 67 \%)$ reported one to five years of working with FHS. $73 \%$ of CHAs and $60 \%$ of nurses had $1-5$ years of experience. $46 \%$ of physicians reported spending 1-5 years with the FHS. The highest proportion of practitioners reported that they had $\leq 250$ cases per month $(n=133 ; 51 \%)$; $91(35 \%)$ reported their caseload was $>501$ cases per month, and 38 practitioners stated that their caseload was between 251 and 500 cases per month (14\%). Seventy-seven percent of CHAs had $\leq 250$ cases per month; $95 \%$ of nurses and $94 \%$ of physicians reported having $>501$ cases per month. Half of the practitioners reported that their commute to work was $0-10 \mathrm{~min}(n=129 ; 50 \%) ; 88$ (34\%) stated their commute ranged from 11-30 min; and $43(16 \%)$ over $30 \mathrm{~min}$. Sixty-seven percent of CHAs reported that their length of commute was $0-10 \mathrm{~min}, 48 \%$ of nurses reported commutes of 11-30 min, and 55\% of physicians reported commutes over $30 \mathrm{~min}$. Ninety-one percent of CHAs said "yes" to the questions asking if they lived in proximity to their work; however, $55 \%$ of nurses and $84 \%$ of physicians answered "no".

Table 2. Demographics and Job Context (Practitioner type).

\begin{tabular}{|c|c|c|c|c|c|}
\hline Demographic Variables & CHAs & Nurses & Physicians & $\begin{array}{c}\text { Total } \\
\text { Sample }\end{array}$ & $p$-Value \\
\hline & $n=169(\%)$ & $n=62(\%)$ & $n=31(\%)$ & $n=262(\%)$ & \\
\hline Race & & & & & $0.002^{a}$ \\
\hline Black & $40(24)$ & $13(21)$ & $1(3)$ & $54(21)$ & \\
\hline White & $42(25.1)$ & $22(35)$ & $18(58)$ & $82(31)$ & \\
\hline Pardo & $85(50.9)$ & $27(44)$ & $11(35)$ & $123(47)$ & \\
\hline Gender & & & & & $<0.001^{\mathrm{a}}$ \\
\hline Male & $28(17)$ & $4(6)$ & $16(52)$ & $48(18)$ & \\
\hline Female & $141(83)$ & $58(94)$ & $15(48)$ & $214(82)$ & \\
\hline Age & & & & & 0.138 \\
\hline 20-30 years & $76(45)$ & $27(44)$ & $12(39)$ & $114(44)$ & \\
\hline $30-40$ years & $56(33)$ & $15(24)$ & $10(32)$ & $81(31)$ & \\
\hline $41-50$ years & $27(16)$ & $12(19)$ & $3(10)$ & $42(16)$ & \\
\hline $51-70$ years & $7(4)$ & $7(11)$ & $5(16)$ & $19(7)$ & \\
\hline FHS experience & & & & & $0.008^{a}$ \\
\hline$\leq 1$ year & $27(16)$ & $8(13)$ & $8(26)$ & $43(16)$ & \\
\hline $1-5$ years & $123(73)$ & $37(60)$ & $15(48)$ & $175(67)$ & \\
\hline $6-15$ years & $19(11)$ & $17(27)$ & $8(26)$ & $44(17)$ & \\
\hline Caseload per Month & & & & & $<0.001^{\mathrm{a}}$ \\
\hline$\leq 250$ & $131(77)$ & $2(3)$ & - & $135(51)$ & \\
\hline $251-500$ & $35(21)$ & $1(2)$ & $2(6)$ & $38(14)$ & \\
\hline$>500$ & $3(2)$ & $59(95)$ & $29(94)$ & $91(35)$ & \\
\hline Length of Commute & & & & & $<0.001^{\mathrm{a}}$ \\
\hline $0-10 \mathrm{~min}$ & $114(67)$ & $12(19)$ & $3(10)$ & $129(50)$ & \\
\hline $11-30 \mathrm{~min}$ & $47(28)$ & $30(48)$ & $11(35)$ & $88(34)$ & \\
\hline$>30 \mathrm{~min}$ & $6(4)$ & $20(32)$ & $17(55)$ & $43(16)$ & \\
\hline Geographic Proximity to work & & & & & $<0.001^{\mathrm{a}}$ \\
\hline Yes & $153(91)$ & $28(45)$ & $5(16)$ & $186(71)$ & \\
\hline No & $15(9)$ & $34(55)$ & $26(84)$ & $75(29)$ & \\
\hline
\end{tabular}




\subsection{Predicting Service Integration}

Of the 262 practitioners, 217 (83\%) reported offering HIV-prevention services; 212 (81\%) engaged in community mobilization; and $118(41 \%)$ engaged in documentation services. Of the 169 CHAs, 142 (83\%) reported offering HIV-prevention services; 138 (82\%) reported mobilizing communities; and $85(51 \%)$ stated they did documentation services. Fifty-three of 62 nurses reported offering HIV-prevention services (85\%); 51 (81\%) stated they mobilized communities; and $14(23 \%)$ engaged in documentation services. Of 31 physicians, 22 (71\%) offered HIV prevention services; 24 (77\%) mobilized communities; and $8(26 \%)$ offered documentation services.

Table 3 shows significant predictors of service integration. None of the demographic or job context variables were significant predictors of service integration, but practitioners with more experience trended toward higher service integration $(\mathrm{B}=0.258 ; p=0.060)$, and $\mathrm{CHAs}$ appear to be more involved in helping consumers obtain documentation/registrations.

Table 3. Standardized estimated direct effects from fully-adjusted structural equation model.

\begin{tabular}{|c|c|c|}
\hline & \multicolumn{2}{|c|}{ Service Integration } \\
\hline & B (SE) & $p$-Value \\
\hline \multicolumn{3}{|l|}{ Demographic } \\
\hline CHAs vs. physicians & 0.373 & 0.118 \\
\hline Nurses vs. physicians & 0.043 & 0.814 \\
\hline Race: black vs. pardo & 0.012 & 0.92 \\
\hline Race: white vs. pardo & -0.182 & 0.125 \\
\hline Male vs. Female & -0.19 & 0.128 \\
\hline Age & 0.15 & 0.236 \\
\hline \multicolumn{3}{|l|}{ Job Context } \\
\hline FHS experience & $0.258^{b}$ & 0.06 \\
\hline Caseload & 0.05 & 0.736 \\
\hline Commute $0-10 \mathrm{~min}$ vs. $>30 \mathrm{~min}$ & -0.122 & 0.595 \\
\hline Commute $11-30 \mathrm{~min}$ vs. $>30 \mathrm{~min}$ & 0.219 & 0.237 \\
\hline Geographic proximity to work & -0.085 & 0.629 \\
\hline \multicolumn{3}{|l|}{ Individual factors } \\
\hline Confidence & $0.322^{\mathrm{a}}$ & 0.02 \\
\hline Knowledge \& skills & $0.448^{\mathrm{a}}$ & 0.006 \\
\hline Familarity with community & 0.153 & 0.177 \\
\hline Perseverance & $0.237^{\mathrm{b}}$ & 0.036 \\
\hline Efficacy of FHS teams & -0.073 & 0.536 \\
\hline \multicolumn{3}{|l|}{ Job Characteristics } \\
\hline Interprofessional collaboration & -0.209 & 0.121 \\
\hline Consumer-Input & 0.033 & 0.819 \\
\hline Skill variety & $0.355^{\mathrm{a}}$ & 0.017 \\
\hline Work-methods autonomy & $-0.222^{b}$ & 0.097 \\
\hline Decision-making autonomy & $-0.237^{b}$ & 0.075 \\
\hline \multicolumn{3}{|l|}{ Organizational factors } \\
\hline Work resources & -0.063 & 0.677 \\
\hline Work conditions & 0.044 & 0.756 \\
\hline
\end{tabular}

a: indicates significant effects when $p<0.05$; $^{\mathrm{b}}$ : indicates significant effects when $p<0.10$; B: Path Coefficients.

Among the individual level factors, confidence $(\mathrm{B}=0.322 ; p=0.020)$, knowledge and skills $(\mathrm{B}=0.448 ; p=0.006)$, and perseverance $(\mathrm{B}=0.237 ; p=0.036)$ had a significant positive effect on integration. Among job characteristics, skill variety had a positive and significant association with service integration $(B=0.355 ; p=0.017)$. Work-methods autonomy $(B=-0.222 ; p=0.097)$ and decision-making autonomy $(\mathrm{B}=-0.237 ; p=0.075)$ trended toward a decreased association with service 
integration. Organizational factors did not show significant associations with service integration. Perseverance was a strong predictor $(\mathrm{MI}=9.345)$ of the provision of HIV-prevention services, even above its effect on overall service integration.

The summary model fit indices for the structural equation model were $\chi^{2}=35.9$ with degrees of freedom $=46$, and the RMSEA was $0.001,90 \%$ Confidence Interval (CI) (0.000-0.024). An RMSEA value of $\leq 0.05$ signifies a good fit. The factor loadings of the three measures of service integration were all significant: HIV-prevention services -0.46 , civil registration -0.43 , community mobilization -0.48 . Overall, the predictors in the model explained $62 \%$ of the variability in service integration.

\section{Discussion}

Integrating HIV prevention while helping consumers to obtain documentation and participate in community activities appears to be commonplace among FHS teams. Results show that greater FHS experience may predict better integration because practitioners who maintain long-term relationships with FHS consumers are likely to know their needs well and thus integrate the most needed services. The longer the time of their employment in the FHS, the better practitioners will be able to identify individual consumer behavior patterns that might lead to disease transmission, and the faster they will act to curtail those behaviors. CHAs are closest to the consumers they serve geographically and have greater knowledge of their community's lifestyles, traditions, and culture than do other members of the FHS team. In making household visits, CHAs study their patients vis-à-vis their sociocultural practices [53]. In doing so, CHAs are the ones best able to identify individual HIV risk behaviors. They appear to be consistently engaging residents in community activities to learn HIV prevention [26,54].

Presumably, FHS team members' awareness of one another's expertise encourages them to consult one another about tasks or services needed for consumers and communities; this generates new knowledge for them. Such consultations ensure that services are integrated in accordance with consumers' needs, and this, in turn, boosts consumer confidence. Service integration requires practitioners to use a combination of clinical, interpersonal, and advocacy skills, along with empathy and compassion toward consumers [18]. It has been established that physicians are given more autonomy than nonmedical practitioners, such as CHAs, [55], due to the perception that their medical and scientific knowledge is superior to the experiential knowledge of CHAs. Indeed, in Brazil, CHAs have reported having less autonomy in making decisions on how to integrate services [56]; nonetheless, our findings suggest that perhaps when motivated and with a sense of social closeness to the communities they serve, CHAs are able and willing to integrate services.

Our results showed that no organizational factors predicted service integration. This may be due to practitioners' perception in recognizing Brazil's poorly managed health system. Their exposure on a daily basis to corruption, lack of governance, and internal bureaucracy, all of which delays the process of buying and delivering supplies and medications, could result in practitioners perseverance in dealing with limitations of a universal health system and in seeking support of FHS team members while delivering integrated services to consumers [57]. However, it is important to note that these results stem from a secondary analysis of FHS data; our choices of quantitative measures were thus limited. Other organizational variables, such as practitioners' job security, remuneration, and job satisfaction, may have improved the explanatory power of our model; however, it is also important to note that no realistic empirical model or dataset could contain every variable that might influence service integration.

Recall and information bias may have affected the reliability of this study's findings. Practitioners who participated were asked to offer information about the previous six months; however, their attitudes might have changed during that time. Data were cross-sectional, making it impossible to determine causal associations; a longitudinal design would allow for a more comprehensive understanding of the associations between variables of interest. Our findings are not generalizable beyond the two municipalities where we collected data. Terms such as "HIV prevention services," "work conditions," and "work resources" were open to interpretation by respondents. The authors also 
identify that certain survey items, such as "I am able to make treatment plans which fit the needs and abilities of my patient", may be double barreled and hence may have resulted in practitioners agreeing to the statement. We thus recommend further research to assess the best ways for measuring these variables, rephrasing survey items to avoid response bias, and include other variables that we did not examine. The authors also recognize that the survey instrument excluded questions on practitioners' training and way of working through the stigma and discrimination faced by people living with HIV, especially those who are members of key populations such as Men who have sex with men (MSM), sex workers, etc. Variables that may improve the model include meeting minutes, assessments, reports, policies, inventory lists of medical equipment, and ways on how practitioners deal with the socio-structural factors impacting consumers. Job-related variables may include practitioners' job security, remuneration, and job satisfaction. Future research may also include a larger sample, including FHS teams from multiple municipalities. Finally, we recommend longitudinal studies to examine relationships between the multi-level factors facilitating service integration and its effect on consumer outcomes. This will assist in creating sophisticated, evidence-based guidelines for service integration.

\section{Implications for Policy and Practice}

Our explanatory model underscores key variables that might inform training to help physicians, nurses, and CHAs improve service integration. Practitioner trainings should focus on harnessing cognitive constructs, such as confidence, perseverance, and knowledge and skills. We recommend training that espouses active, problem-based, and action learning in order to reflect real-world practices. The need to address complex health promotion in the context of community factors calls for recognizing the limits of individual practitioner expertise so that practitioners can leverage the expertise of colleagues to provide comprehensive care to consumers. Diversity of expertise within FHS teams is important so that clinical expertise (physicians and nurses) may merge with experiential knowledge (CHAs) to solve complex health issues. We recommend that FHS health care managers/administrators work together to provide curricula/trainings that focus on service integration. Academic and FHS collaboration curricula ought to include the input of both CHAs and medical staff. The purpose of including CHAs in curricular design is to ensure that community-based skills are included in training/education initiatives.

\section{Conclusions}

This study shows that practitioners in Brazil's FHS are likely to provide HIV education while helping individuals obtain documentation for receiving primary care and welfare services, and to participate in health promotion community activities. Our major contribution is an explanatory model that can be adapted to examine the impact of other variables that might influence integration of other services. This model can also be adapted to study service integration in primary care systems in other countries.

Acknowledgments: The authors thank the Columbia University School of Social Work and the Institute for Latin American Studies at Columbia University for supporting this research with pilot and dissemination funding, respectively. We thank research participants who graciously provided the data for this research. We also thank the following: Estratégia Saúde da Família providers and administrators critical to the execution of this research Ivanete Hindriches da S. Torres, Roselí Monteiro Silva, Gilberto da Silva Dorneles, Paulo de Tarso Machado Assis, Maria do Carmo de Castro Tófani, and Nádia Cristina Dias Duarte; our partners at Universidade Católica Rio de Janeiro Sueli Bulhões da Silva, and Luíza Helena Nunes Ermel; and individuals who provided overall support-Susan Witte, Margareth Zanchetta, and Barbara L. Simon.

Author Contributions: R.R. participated in the analysis and interpretation of data, and writing of the manuscript. R.M.P. participated in the design and execution of the study, and contributed to critical revisions of the manuscript. M.W. contributed analysis tools. All authors read and approved the final manuscript.

Conflicts of Interest: The authors declare no conflict of interest. The founding sponsors had no role in the design of the study; in the collection, analyses, or interpretation of data; in the writing of the manuscript, and in the decision to publish the results. 


\section{References}

1. Singh, G.K.; Azuine, R.E.; Siahpush, M. Global inequalities in cervical cancer incidence and mortality are linked to deprivation, low socioeconomic status, and human development. Int. J. MCH AIDS (IJMA) 2015, 1, 17-30. [CrossRef]

2. Arreola, S.; Santos, G.-M.; Beck, J.; Sundararaj, M.; Wilson, P.A.; Hebert, P.; Makofane, K.; Do, T.D.; Ayala, G. Sexual stigma, criminalization, investment, and access to HIV services among men who have sex with men worldwide. AIDS Behav. 2015, 19, 227-234. [CrossRef] [PubMed]

3. Thornton, R.L.; Glover, C.M.; Cené, C.W.; Glik, D.C.; Henderson, J.A.; Williams, D.R. Evaluating strategies for reducing health disparities by addressing the social determinants of health. Health Aff. 2016, 35, 1416-1423. [CrossRef] [PubMed]

4. Joint United Nations Programme on HIV / Acquired Immune Deficiency Syndrome (UNAIDS). Prevention Gap Report. 2016. Available online: http://www.unaids.org/sites/default/files/media_asset/2016prevention-gap-report_en.pdf (accessed on 18 December 2016).

5. Dean, H.D.; Fenton, K.A. Addressing social determinants of health in the prevention and control of HIV/AIDS, viral hepatitis, sexually transmitted infections, and tuberculosis. Public Health Rep. 2010, 125, 1-5. [CrossRef] [PubMed]

6. Herman, A.A. Community health workers and integrated primary health care teams in the 21st century. J. Ambul. Care Manag. 2011, 34, 354-361. [CrossRef] [PubMed]

7. $\quad$ Baral, S.D.; Friedman, M.R.; Geibel, S.; Rebe, K.; Bozhinov, B.; Diouf, D.; Sabin, K.; Holland, C.E.; Chan, R.; Cáceres, C.F. Male sex workers: Practices, contexts, and vulnerabilities for HIV acquisition and transmission. Lancet 2015, 385, 260-273. [CrossRef]

8. Naidoo, P.; Chirinda, W.; Mchunu, G.; Swartz, S.; Anderson, J. Social and structural factors associated with vulnerability to HIV infection among young adults in South Africa. Psychol. Health Med. 2015, 20, 369-379. [CrossRef] [PubMed]

9. Valentijn, P.; Boesveld, I.C.; van der Klauw, D.M.; Ruwaard, D.; Struijs, J.N.; Molema, J.J.W.; Bruijnzeels, M.A.; Vrijhoef, H.J.M. Towards a taxonomy for integrated care: A mixed-methods study. Int. J. Integr. Care 2015, 15. [CrossRef]

10. Winters, S.; Magalhaes, L.; Kinsella, E.A.; Kothari, A. Cross-sector service provision in health and social care: An umbrella review. Int. J. Integr. Care 2016, 16. [CrossRef]

11. Shigayeva, A.; Atun, R.; McKee, M.; Coker, R. Health systems, communicable diseases and integration. Health Policy Plan. 2010, 25, 4-20. [CrossRef] [PubMed]

12. Spector, A.Y.; Pinto, R.M.; Rahman, R.; da Fonseca, A. Implementation of Brazil's "Family Health Strategy": Factors associated with community health workers', nurses', and physicians' delivery of drug use services. Int. J. Drug Policy 2015, 26, 509-515. [CrossRef] [PubMed]

13. Ghesquiere, A.R.; Pinto, R.M.; Rahman, R.; Spector, A.Y. Factors Associated with Providers' Perceptions of Mental Health Care in Santa Luzia's Family Health Strategy, Brazil. Int. J. Environ. Res. Public Health 2015, 13, 33. [CrossRef] [PubMed]

14. Unützer, J.; Katon, W.J.; Fan, M.-Y.; Schoenbaum, M.C.; Lin, E.H.B.; Della Penna, R.D.; Powers, D. Long-term cost effects of collaborative care for late-life depression. Am. J. Manag. Care 2008, 14, 95-100. [PubMed]

15. Ockene, J.K.; Marion, L.N.; Loveland-Cherry, C.J. Integrating evidence-based clinical and community strategies to improve health. Am. J. Prev. Med. 2007, 32, 244-252. [CrossRef] [PubMed]

16. Unützer, J.; Tang, L.; Oishi, S.; Katon, W.; Williams, J.W., Jr.; Hunkeler, E.; Hendrie, H.; Lin, E.H.B.; Levine, S.; Grypma, L.; et al. Reducing suicidal ideation in depressed older primary care patients. J. Am. Geriatr. Soc. 2006, 54, 1550-1556. [CrossRef] [PubMed]

17. Brown, L.; Tucker, C.; Domokos, T. Evaluating the impact of integrated health and social care teams on older people living in the community. Health Soc. Care Commun. 2003, 11, 85-94. [CrossRef]

18. Pinto, R.M.; Wall, M.; Yu, G.; Penido, C.; Schmidt, C. Primary care and public health services integration in Brazil's Unified Health System. Am. J. Public Health 2012, 102, 69-76. [CrossRef] [PubMed]

19. Paim, J.; Travassos, C.; Almeida, C.; Bahia, L.; Macinko, J. The Brazilian health system: History, advances, and challenges. Lancet 2011, 377, 1778-1797. [CrossRef] 
20. WHO, Global Health Workforce Alliance. Global Experience of Community Health Workers for Delivery of Health Related Millennium Development Goals: A Systematic Review, Country Case Studies, and Recommendations for Integration Into national Health Systems; WHO, Global Health Workforce Alliance: Geneva, Switzerland, 2010.

21. Brazil Ministry of Health. Recommendations on Antiretroviral Therapy in HIV-Infected Adults and Adolescent; Department of STD, AIDS and Viral Hepatitis: Brasília, DF, Brazil, 2006. Available online: http:/ /www.aids. gov.br/ (accessed on 13 December 2013).

22. Silva, T.L.; Dias, E.C.; Ribeiro, E.C.D.O. Knowledge and practices of Community Health Agents in workers' healthcare. Interface-Comun. Saúde, Educ. 2011, 15, 859-870. [CrossRef]

23. Howarth, C.; Campbell, C.; Cornish, F.; Franks, B.; Garcia-Lorenzo, L.; Gillespie, A.; Gleibs, I.; Gonvales-Portelinha, I.; Jovchelovitch, S.; Lahlou, S.; et al. Insights from Societal Psychology: The contextual politics of change. J. Soc. Polit. Psychol. 2013, 1, 364-384. [CrossRef]

24. Gilkey, M.; Garcia, C.C.; Rush, C. Professionalization and the experience-based expert: Strengthening partnerships between health educators and community health workers. Health Promot. Pract. 2011, 12, 178-182. [CrossRef] [PubMed]

25. Pinto, R.M.; da Silva, S.B.; Soriano, R. Community Health Workers in Brazil's Unified Health System: A framework of their praxis and contributions to patient health behaviors. Soc. Sci. Med. 2012, 74, 940-947. [CrossRef] [PubMed]

26. Zanchetta, M.S.; Pinto, R.M.; Galhego-Garcia, W.; da Cunha, Z.; Cordeiro, H.A.; Fagundes-Filho, F.E.; Pinho, M.A.L.; Voet, S.M.V.; Talbot, Y.; Caldas, R.S.; et al. Brazilian Community Health Agents and qualitative primary healthcare information. Prim. Health Care Res. Dev. 2014, 16, 235-245. [CrossRef] [PubMed]

27. Brownstein, J.N.; Hirsch, G.R.; Rosenthal, E.L.; Rush, C.H. Community Health Workers "101" for Primary Care Providers and Other Stakeholders in Health Care Systems. J. Ambul. Care Manag. 2011, 34, 210-220. [CrossRef] [PubMed]

28. Ammentorp, J.; Sabroe, S.; Kofoed, P.E.; Mainz, J. The effect of training in communication skills on medical doctors' and nurses' self-efficacy: A randomized controlled trial. Patient Educ. Couns. 2007, 66, 270-277. [CrossRef] [PubMed]

29. Ivbijaro, G.; Patel, V.; Chisholm, D.; Goldberg, D.; Khoja, T.A.; Edwards, T.M.; Enum, Y.; Kolkiewic, L.A. Informing mental health policies and services in the EMR: Cost-effective deployment of human resources to deliver integrated community-based care. East Mediterr. Health J. 2015, 21, 486-492. [PubMed]

30. Cotton, P.; Hart, P.M. Occupational wellbeing and performance: A review of organisational health research. Aust. Psychol. 2003, 38, 118-127. [CrossRef]

31. Frigo, J.; Costa, E.R.; Kolhs, M.; Busnello, G. Tasks performed by professional nurses in family health strategy. J. Nurs. UFPE 2013, 7, 5421-5426.

32. Magalhães, K.A.; Cotta, R.M.M.; de Castro Pereira Martins, T.; Gomes, A.P.; Siqueira-Batista, R. Habitation as a Social Determinant of Health: Perceptions and conditions of families registered under the "Bolsa Família" Program. Saúde Soc. 2013, 22, 57-72.

33. Falavigna, A.; Canabarro, C.T.; Medeiros, G.S. Health System and Medical Education in Brazil: History, Principles, and Organization. World Neurosurg. 2013, 80, 723-727. [CrossRef] [PubMed]

34. Teles, M.A.; Barbosa, M.R.; Vargas, A.M.D.; Gomes, V.E.; e Ferreira, E.F.; de Barros Lima Martins, A.M.E.; Ferreira, R.C. Psychosocial work conditions and quality of life among primary health care employees: A cross sectional study. Health Q. Life Outcomes 2014, 12, 72. [CrossRef] [PubMed]

35. Morgeson, F.P.; Humphrey, S.E. Job and team design. In Research in Personnel and Human Resources Management; Morgeson, F.P., Ed.; Emerald Group Publishing Limited: Bingley, UK, 2008; pp. 39-92.

36. Obi-Nwosu, H.; Joe-Akunne Chiamaka, O. Job Characteristics as Predictors of Organizational Commitment among Private Sector Workers in Anambra State, Nigeria. Int. J. Asian Soc. Sci. 2013, 3, 482-491.

37. Brazil Ministry of Health—Secretariat of Health Care. National Primary Health Care Policy. 2012. Available online: http:/ /189.28.128.100/dab/docs/publicacoes/geral/pnab.pdf (accessed on 20 December 2016).

38. Barry, M.J.; Edgman-Levitan, S. Shared decision making-The pinnacle of patient-centered care. N. Engl. J. Med. 2012, 366, 780-781. [CrossRef] [PubMed]

39. Coelho, F.; Augusto, M. Job characteristics and the creativity of frontline service employees. J. Serv. Res. 2010, 13, 426-438. [CrossRef]

40. Oldham, G.R.; Hackman, J.R. Not what it was and not what it will be: The future of job design research. J. Organ. Behav. 2010, 31, 463-479. [CrossRef] 
41. Hackman, J.R.; Oldham, G.R. Development of the job diagnostic survey. J. Appl. Psychol. 1975, 60, $159-170$. [CrossRef]

42. Brown, L.D.; Covey, J.G. Development organizations and organization development: Towards an expanded paradigm for organization development. In Research in Organizational Change and Development; Woodman, R.W., Pasmore, W.A., Eds.; JAI Press: Greenwich, CT, USA, 1987.

43. Burns, T.E.; Stalker, G.M. The Management of Innovation; Tavistock Publisher: London, UK, 1961.

44. Lawrence, P.R.; Lorsch, J.W. Organization and Environment: Managing Differentiation and Integration; Division of Research, Graduate School of Business Administration, Harvard University Boston: Boston, MA, USA, 1967.

45. Pinto, R.M.; Spector, A.Y.; Witte, S.S.; Gilbert, L. Systematizing planning and formative phases of HIV prevention research: Case studies from Brazil, Mongolia, and Kazakhstan. Glob. Soc. Welf. 2014, 1, 137-144. [CrossRef] [PubMed]

46. Pinto, R.M.; Bulhões da Silva, S.; Penido, C.; Spector, A.Y. International participatory research framework: Triangulating procedures to build health research capacity in Brazil. Health Promot. Int. 2012, 27, 435-444. [CrossRef] [PubMed]

47. DATSTAT Illume. DATSTAT (Data Management Software); DATSTAT Illume: Seattle, WA, USA, 1997.

48. Brislin, R.W. Back-translation for cross-cultural research. J. Cross-Cult. Psychol. 1970, 1, 185-216. [CrossRef]

49. Telles, E.E. Race in Another America: The Significance of Skin Color in Brazil; Princeton University Press: Princeton, NJ, USA, 2004.

50. Cohen, J.; Cohen, P. Applied multiple Regression/Correlation Analysis for the Behavioral Sciences, 2nd ed.; Lawrence Erlbaum: New Jersey, NJ, USA, 1983.

51. Ho, R. Handbook of Univariate and Multivariate Data Analysis with IBM SPSS, 2nd ed.; CRC Press: Boca Raton, FL, USA, 2013.

52. Kelloway, E.K. Using Mplus for Structural Equation Modeling: A Researcher's Guide, 2nd ed.; Sage Publications: London, UK, 2014.

53. Rocha, N.H.N.; Barletto, M.; Bevilacqua, P.D. Identity of community health agents: Composing emerging rationalities. Interface-Comun. Saúde Educ. 2013, 17, 847-857. [CrossRef]

54. Mwai, G.W.; Mburu, G.; Torpey, K.; Frost, P.; Ford, N.; Seeley, J. Role and outcomes of community health workers in HIV care in sub-Saharan Africa: A systematic review. J. Int. AIDS Soc. 2013, 16. [CrossRef] [PubMed]

55. Lin, B.Y.; Lin, Y.K.; Lin, C.C.; Lin, T.T. Job autonomy, its predispositions and its relation to work outcomes in community health centers in Taiwan. Health Promot. Int. 2013, 28, 166-177. [CrossRef] [PubMed]

56. Dos Santos Pedrosa, J.I.; Teles, J.B.M. Agreements and disagreements in the Family Health Care Program team. Rev. Saúde Pública 2001, 35, 303-311.

57. Silveira, D.S.; Facchini, L.A.; Vinholes Siqueira, F.; Piccini, R.X.; Tomasi, E.; Thumé, E.; Manjourany Silva, S.; Dilélio, A.S.; dos Santos Maia, M.F. Management of work, education, information, and communication in primary healthcare in cities in Southern and Northeastern Brazil. Cadernos Saúde Pública 2010, 26, 1714-1726. [CrossRef]

(C) 2017 by the authors. Licensee MDPI, Basel, Switzerland. This article is an open access article distributed under the terms and conditions of the Creative Commons Attribution (CC BY) license (http:/ / creativecommons.org/licenses/by/4.0/). 